\title{
Early Diagnosis of Multiple Endocrine Neoplasia Type 2B: a Challenge for Physicians
}

\begin{abstract}
Background: The hereditary form of medullary thyroid carcinoma may occur isolated as a familial medullary thyroid carcinoma (FMTC) or as part of Multiple Endocrine Neoplasia 2A (MEN2A) and 2B (MEN2B). MEN2B is a rare syndrome, its phenotype may usually, but not always, be noted by the physician. In the infant none of the MEN2B characteristics are present, except by early gastrointestinal dysfunction caused by intestinal neuromas. When available, genetic analysis confirms the diagnosis and guides pre-operative evaluation and extent of surgery. Here we report four cases of MEN2B in which the late diagnosis had a significant impact in clinical evolution and, potentially, in overall survival. Case Report: We report four cases, 2 men and 2 women, with differences in their phenotypes and with a late diagnosis. The first case has a history of severe gastrointestinal obstruction requiring a surgery intervention two days after his birth. The second told had nodules in the oral mucosa and constipation since childhood. The third case referred a history of constipation from birth until 5 months of life. The fourth has had a history of chronic constipation since childhood. Discussion: New concepts have emerged since the RET oncogene was identified in 1993 as the responsible gene for hereditary medullary thyroid carcinoma. The majority of MEN2B individuals have M918T mutation in the exon 16 of $R E T$, with a few cases having a mutation $A 883 F$ or the association of V804M with E805K, Y806C or S904C mutations. The consensus classifies the RET mutation in codon 918 as of highest risk and recommends total thyroidectomy and central lymph node dissection until 6 months after birth. A fast and precise diagnosis is essential to reach these goals. The identification of early manifestations such as intestinal ganglioneuromatosis and oral mucosal neuromas should prompt the physician to initiate an investigation for multiple endocrine neoplasia type 2B. Conclusion: The diagnosis of MEN2B is very important to allow appropriate investigation of associated diseases and to allow counseling and appropriate screening of relatives for a $R E T$ mutation. Even patients with MEN2B, which often have typical physical features, may not be properly recognized and be followed as a sporadic case. Based on this, all suspicious cases of multiple endocrine neoplasia should undergo a molecular genetic test. (Arq Bras Endocrinol Metab 2008; 52/8:1393-1398)
\end{abstract}

Keyword: Medullary thyroid carcinoma; MEN2B; M918T; Phenotype and intestinal ganglioneuromatosis

\section{RESUMO}

Diagnóstico Precoce de Neoplasia Endócrina Múltipla Tipo 2B: um Desafio para os Médicos.

A forma hereditária do carcinoma medular da tiróide pode ocorrer de modo isolado, o carcinoma medular da tiróide familiar (FMTC), ou como parte das neoplasias endócrinas múltiplas tipo 2A (MEN2A) e 2B (MEN2B). MEN2B é uma síndrome rara e seu fenótipo é usualmente, mas nem sempre, notado pelo médico. Na infância, nenhuma das características de MEN2B estão pre- perspectives

Cleber P. Camacho

ANA O. HOFF

SUSAN C. LINDSEY

PRISCILA S. SIGNORINI

FLÁVIA O. F. VALENTE

MARIANA N. L. OliveIRA

ILDA S. KUNII

Rosa Paula M. Biscolla

JANETE M. CERUTII

RUI M. B. MACIEL

Laboratory of Molecular Endocrinology, Division of Endocrinology, Department of Medicine, Federal University of São Paulo (CPC, AOH, SCL, PSS, FFV, MN, RPMB, JMC, RMBM); Fleury-Medicina e Saúde $(\mathrm{AOH}$, RPMB, RMBM), São Paulo, SP, Brazil.

Received in 2/9/2008

Accepted in 29/10/2008 
sentes, exceto pela disfunção gastrintestinal precoce, causada pelos neuromas intestinais. Quando disponível, a análise genética confirma o diagnóstico e orienta a avaliação pré-operatória e extensão da cirurgia. Neste artigo, apresentamos quatro casos de MEN2B, nos quais o diagnóstico tardio teve impacto significativo na evolução clínica e, potencialmente, na mortalidade em geral. Apresentação dos casos: Apresentamos quatro casos, dois homens e duas mulheres, com diferenças em seus fenotipos e com diagnóstico tardio. $O$ primeiro caso tem história de obstrução gastrintestinal importante em que foi necessária cirurgia dois dias após o nascimento. O segundo paciente apresentava nódulos na mucosa oral e constipação desde a infância. $O$ terceiro referia história de constipação desde o nascimento até 5 meses de idade. O quarto tinha história de constipação intestinal desde a infância. Discussão: Novos conceitos emergiram desde que o oncogene RET foi identificado, em 1993, como o gene responsável pelo carcinoma medular da tiróide hereditário. A maioria dos indivíduos apresenta a mutação M918T no éxon 16 do RET, enquanto poucos casos apresentam a mutação A883F ou a associação de V804M com E805K, Y806C ou S904C. O consenso recomenda a tiroidectomia total com dissecção dos linfonodos no compartimento central até os 6 meses após o nascimento. 0 diagnóstico rápido e preciso é essencial para o atingir os objetivos. Conclusão: $\mathrm{O}$ diagnóstico precoce de MEN2B é muito importante para propiciar a investigação apropriada de doenças associadas e para permitir aconselhamento e rastreamento dos parentes para uma mutação do RET. Pacientes com MEN2B, que apresentam frequentemente achados típicos ao exame físico, podem não ser reconhecidos e seguidos como casos esporádicos. Por causa disso, todos os casos de neoplasia endócrina múltipla devem ser avaliados pelo teste genético para mutações do RET. (Arq Bras Endocrinol Metab 2008; 52/8:1393-1398)

Descritores: Carcinoma medular de tiróide; MEN2B; M918T; Fenótipo; Ganglioneuromatose intestinal

\section{INTRODUCTION}

he hereditary form of medullary thyroid carcinoma may occur isolated as a familial medullary thyroid carcinoma (FMTC) or as part of Multiple Endocrine Neoplasia 2A (MEN2A) and 2B (MEN2B). The Multiple Endocrine Neoplasia 2B represents an inherited autosomal dominant syndrome characterized by medullary thyroid carcinoma, pheochromocytoma, mucosal neuromas, ganglioneuromatosis of the gut and marfanoid habitus (1). Although MEN2B is a rare syndrome, its phenotype may usually, but not always, be noted by the physician.

The clinical diagnosis of MEN2B may be facilitated by the identification of a characteristic phenotype which includes distinctive facial features such as thickened lips and elongated face, a "marfanoid" body habitus, mucosal neuromas (of lips, buccal mucosa, tongue, eyelids, palate and intestinal mucous membrane), thickened medullated corneal nerves (on slitlamp examination), skeletal abnormalities (kyphoscoliosis, joint laxity and pes cavus) in addition to medullary carcinoma of the thyroid and pheochromocytoma (2) (Table 1).
Table 1. List of signs and symptoms of MEN2B and their frequencies.

\begin{tabular}{|c|c|}
\hline Clinical characteristics & Frequency \\
\hline $\begin{array}{l}\text { Mucosal neuromas of the lips, eyelids, } \\
\text { buccal mucosa, tongue, palate and } \\
\text { intestinal mucous membrane (earliest sign) }\end{array}$ & $100 \%$ \\
\hline Enteric Ganglioneuromatosis & $100 \%$ \\
\hline $\begin{array}{l}\text { Medullary carcinoma of the thyroid (very } \\
\text { young child) }\end{array}$ & $90 \%$ \\
\hline $\begin{array}{l}\text { Skeletal abnormalities of the spine (lordosis, } \\
\text { kyphosis, scoliosis), talipes equinovarus, } \\
\text { kyphoscoliosis, joint laxity and) and pes } \\
\text { cavus }\end{array}$ & common \\
\hline \multicolumn{2}{|l|}{$\begin{array}{l}\text { Thickened medullated corneal nerves } \\
\text { (slitlamp examination) }\end{array}$} \\
\hline \multicolumn{2}{|l|}{ Facies with thickened lips } \\
\hline Marfanoid habitus & $65-75 \%$ \\
\hline Pheochromocytoma & $45-50 \%$ \\
\hline
\end{tabular}


On the other hand, in the infant, none of these characteristics are present, except by early gastrointestinal dysfunction caused by intestinal neuromas (3). Intestinal ganglioneuromatosis can lead to severe constipation and megacolon simulating Hirschsprung's disease (4-7). In fact, Hirschsprung's disease may also occur with MEN2B (8).

The early onset and aggressiveness of medullary thyroid cancer in MEN2B requires an early diagnosis and treatment. It is critical that these cases are identified in the first year of life so that early thyroidectomy is performed. When available, genetic analysis confirms the diagnosis and guides pre-operative evaluation and extent of surgery (6).

Here we report four cases of MEN2B in which the late diagnosis had a significant impact in clinical evolution and, potentially, in overall survival.

\section{CASE REPORTS}

\section{First case}

A 20 year-old man had a thyroid nodule diagnosed when he was 12 years old, following non-specific throat complaints. He subsequently saw an endocrinologist who made the diagnosis of MTC through a serum calcitonin of $18750 \mathrm{pg} / \mathrm{mL}$. He underwent total thyroidectomy at the age of 14 , but only a partial resection was achieved. He then received systemic chemotherapy with multiple drugs for four years and is now on imatinib (Gleevec $®)$. During the treatment, one year after the thyroidectomy, lung nodules were found in a CT scan.

The past medical history was significant for severe gastrointestinal obstruction requiring a surgery intervention two days after his birth and an orthopedic surgery for a bone fracture after a fall at the age of 11 . There was no family history of endocrine diseases.

In his last clinical visit, at the age of 20 , the physical examination revealed a normal blood pressure, a weight of $43.8 \mathrm{~kg}$, height of $181 \mathrm{~cm}$ with an arm span of $175 \mathrm{~cm}$ and the presence of mucosal neuromas in the tongue. He brought a hip x-ray which showed femoral deformities (Figure 1A).

The genetic analysis revealed a mutation of the RET proto-oncogene, M918T (Figure 2A).
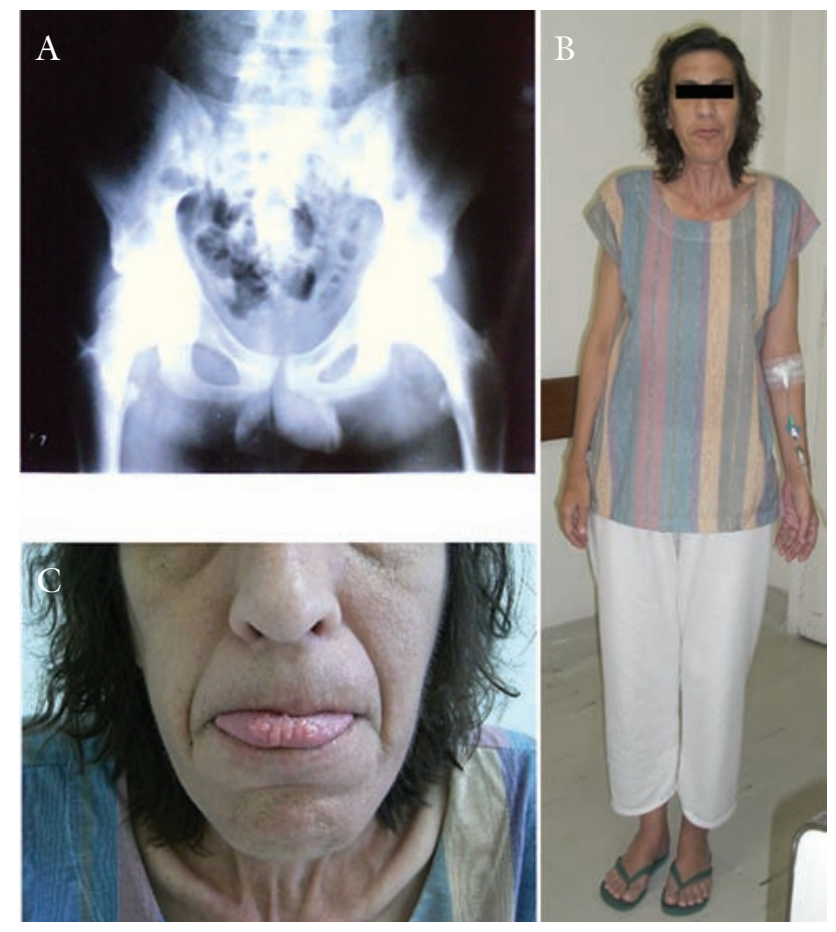

Figure 1. A) Hip X-Ray of first case showing a long and laterally-displaced femoral neck; B) fourth patient clinical characteristics; C) mucosal neuromas in the tongue of fourth patient.

A

$A A A T G G A N G G C A A T T$

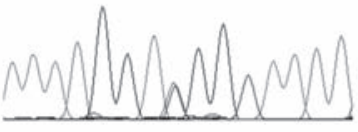

C

$A A A T G O A N G O C A A T T$

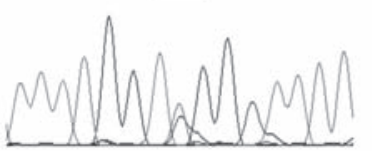

$\mathrm{B}$ $\underset{190}{A A}$ GGA GGCAAT I

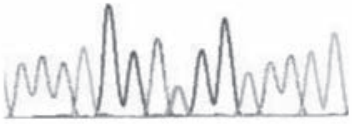

$\mathrm{D}$
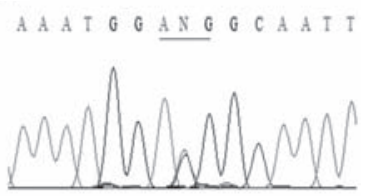

Figure 2. Eletropherograms of the reported cases with exon 16 RET mutation at codon 918 (ATG>ACG).

\section{Second case}

A 23 year-old man with complaints of sweating, hypertension $(170 \times 110 \mathrm{mmHg}$ in more than one ocasion) and headache for 18 months was diagnosed with a nearly five-centimeter pheochromocytoma in the right adrenal gland and then underwent adrenalectomy. 
Prior to the surgery, on physical examination, a thyroid nodule was noticed. Thyroid ultrasound confirmed it to be a thyroid nodule in the right lobe, measuring $1.4 \mathrm{~cm}$ in diameter and with central calcification. Fine needle aspiration cytology confirmed a MTC. Three months after the adrenalectomy, the patient underwent total thyroidectomy with bilateral neck dissection and pathology revealed a multifocal medullary carcinoma with lymph-node involvement and extrathyroidal extension.

Upon questioning, he told he had nodules in the oral mucosa and constipation since childhood. On physical examination mucosal neuromas in the tongue were observed and there were no other remarkable features.

He was then submitted to close clinical follow-up. An abdominal CT scan revealed bilateral nephrolithiasis and an enlarged colon. A MIBG scintigraphy showed high uptake in left adrenal gland. To better investigate the MIBG findings, a magnetic resonance imaging (MRI) was obtained which revealed a $1.1 \mathrm{~cm}$ nodule in the left adrenal gland with characteristics of a pheochromocytoma. A left adrenalectomy was performed confirming a pheochromocytoma.

$\mathrm{He}$ also had a femoral fracture after an accident.

The DNA analysis revealed a mutation of the codon 918 of the RET oncogene (M918T) (Figure 2B).

\section{Third case}

A 21 year-old woman presented a thyroid nodule at the age of 16, which was diagnosed as a medullary thyroid carcinoma. She underwent a total thyroidectomy and pathology revealed multifocal medullary thyroid carcinoma (largest lesion measuring $4.5 \times 2.7 \mathrm{~cm}$ ) associated with extra-thyroidal invasion, $\mathrm{C}$ cell hyperplasia and lymph-node involvement.

Several months later she was found to have locallyrecurrent disease and underwent a limited neck dissection with removal of a small number of lymph-nodes. Post-operatively, due to the persistence of high serum calcitonin levels, she was treated with external-beam radiotherapy.

Three years later, she complained of diarrhea and weakness. At this time serum calcitonin was significantly abnormal $(18004 \mathrm{pg} / \mathrm{mL})$ and a CT scan of the chest revealed multiple nodules in the lungs confirmed to be metastatic MTC by a biopsy. Prior to the referral to our institution, she underwent a left cervical neck dissection which failed to identify metastatic lymphnodes.

She was then referred to our institution for further evaluation and management. Upon questioning she admitted to have had episodes of headache, palpitations and sweating lasting approximately three minutes, two to three times a week. In addition, she referred a history of constipation from birth until 5 months of life. There is no family history of medullary thyroid carcinoma, however, her father died at a young age from an unknown cause.

On physical examination, the blood pressure was $120 \times 70 \mathrm{mmHg}$ (lying) and $100 \times 70 \mathrm{mmHg}$ (standing up), height was $171 \mathrm{~cm}$, her arm span was 170 $\mathrm{cm}$. Other remarkable features included a thin and elongated face, thickened lips and mucosal neuromas in the tongue.

The laboratory evaluation included high levels of calcitonin $(>20.000 \mathrm{pg} / \mathrm{mL})$ and CEA $(423.7 \mu \mathrm{g} / \mathrm{L})$ and normal levels of PTH and calcium. The urinary metanephrines were measured twice and total metanephrines were found to be elevated $(1954 \mu \mathrm{g} / 24 \mathrm{~h}$ and $1556 \mu \mathrm{g} / 24 \mathrm{~h}$, normal values 95 to $425 \mu \mathrm{g} / 24 \mathrm{~h}$ ).

A MIBG scan revealed moderate adrenal uptake, more intense in the left adrenal gland. MRI found slight thickening of both the adrenal glands with no specific lesions indicating a pheochromocytoma. Due to evidence of catecholamine hyper secretion without the localization of a pheochromocytoma, she was started on prazosin $1 \mathrm{mg} /$ day and she has remained clinically stable.

Additionally, the MRI revealed liver lesions suspicious for metastasis and a vertebral lesion also suspicious for metastatic disease. A recent neck ultrasound revealed a mass in the left thyroid bed measuring $27 \times 16$ $\mathrm{mm}$ and two suspicious lymph nodes in the right cervical area. Due to the finding of progressive and widely metastatic disease she is under evaluation for systemic therapy.

The DNA analysis revealed a M918T RET mutation (Figure 2C).

\section{Fourth case}

A 46 year-old woman was diagnosed with a thyroid nodule 30 years ago. She was treated with total thyroidectomy and cervical dissection and received external-beam radiotherapy one year later. 
The patient was recently evaluated at our institution and she then complained of weight loss, diarrhea (10 bowel movements a day) and dyspnea in the past year and a half. Before the diarrhea started she had chronic constipation (since childhood). In the past four weeks she had been having paroxysmal hypertension which led her to increase the anti-hypertensive drugs dosage by her own. Systolic blood pressure levels varied from $200 \mathrm{mmHg}$ to $50 \mathrm{mmHg}$ and during the hypertensive episodes she describes that she felt "as her chest was going to explode". In addition, she refers that she has been evaluated by an ophthalmologist who observed "a MEN-related eye manifestation".

The family history is significant for a grandmother with history of a goiter, mother who died from diabetes complications at age 83 and a father who died from hypertension at the age of 87 . She has a 16 year-old daughter who is healthy and apparently has no thyroid disease.

Physical examination findings were orthostatic hypotension ( $140 \times 90 \mathrm{mmHg}$ lying and $90 \times 70 \mathrm{mmHg}$ standing), height of $1.72 \mathrm{~m}$ and an arm span of $1.62 \mathrm{~m}$, an elongated face with thickened lips and mucosal neuromas in the tongue (Figures $\mathrm{IB}$ and $\mathrm{IC}$ ).

Laboratory evaluation revealed a high serum calcitonin level $(2800 \mathrm{pg} / \mathrm{mL})$, an elevated CEA (132 $\mu \mathrm{g} / \mathrm{L}$ ) and elevated urinary metanephrines.

MRI found multiples nodules in right lobe of the liver, cholelithiasis, a mass in the right adrenal gland measuring $11,7 \mathrm{~cm}$ and a mass in the left adrenal measuring $4.7 \mathrm{~cm}$. A CT scan of the chest showed diffuse interstitial lung abnormalities which are under diagnostic evaluation .

DNA analysis revealed a M918T RET mutation (Figure 2D).

The patient was started on prazosin $1 \mathrm{mg} /$ day and her blood pressure levels are now normal. She is currently under evaluation and preparation for bilateral adrenalectomy.

\section{DISCUSSION}

New concepts have emerged since the RET proto-oncogene was identified in 1993 as the responsible gene for hereditary medullary thyroid carcinoma. The identification of the genotype-phenotype correlations including age-related development of disease, association with other manifestations such as pheochromocytoma and hyperparathyroidism and the codon-specific aggressiveness of medullary thyroid carcinoma has enriched the physician's knowledge of the disease and facilitated the management of the individual patient and of kindreds with MEN2. Specifically, it has become clear that, for MEN2B patients, the chance for a better outcome is the early diagnosis and treatment and the proper screening of family members $(9,10)$.

The majority of MEN2B individuals have M918T mutation in exon 16, with a few cases having a mutation $\mathrm{A} 883 \mathrm{~F}$ or the association of V804M with E805K, Y806C or S904C mutations (11-15). The consensus established in the last International Workshop on Multiple Endocrine Neoplasia classifies the RET mutation in codon 918 as highest risk and recommends total thyroidectomy and central lymph node dissection until 6 months after birth. A fast and precise diagnosis is essential to reach these goals.

In this report, we describe four patients with MEN2B and incurable MTC due to late diagnosis. The diagnosis of MEN2B is frequent late, especially when there is no family history of MEN2B. In newborns, the characteristic MEN2B phenotype is often absent and the only common manifestation is constipation due to intestinal ganglioneuromatosis. In fact, all our four patients with MEN2B had severe constipation during infancy. It would be important to include MEN2B as a differential diagnosis of severe constipation and congenital megacolon as, although rare, an early diagnosis of MEN2B could lead to appropriate treatment and potential cure $(6,16,17)$.

Other characteristics that could alert physicians of a MEN2B diagnosis include the finding of thickened corneal nerve upon an ophthalmologic evaluation as observed in patient 4 and the presence of skeletal manifestations such as scoliosis, kyphosis, lordosis, joint laxity, slipped capital femoral epiphyses and pes cavus (18-19). Although only one of the four patients has orthopedic complaints, the alterations may be common and guide the physician to the diagnosis of MEN2B.

The reported patients have characteristics such as the elongated face with thickened lips and mucosal neuromas, but not the classical marfanoid habitus, represented by an arm span bigger than the height. The mucosal neuromas are the earliest signs and are present in almost all patients with MEN2B. Even in the absence of other signs or symptoms, the presence of mucosal neuromas in the early ages should motivate a MEN2B investigation. 
The complete syndrome with mucosal neuromas, pheochromocytoma and MTC occurs in only $50 \%$ of the cases and when present is already too late for a prophylactic approach. The identification of early manifestations such as intestinal ganglioneuromatosis and oral mucosal neuromas should prompt the physician to initiate an investigation for multiple endocrine neoplasia type $2 \mathrm{~B}$.

\section{CONCLUSION}

The diagnosis of MEN2B is very important to allow appropriate investigation of associated diseases and to allow counseling and appropriate screening of relatives for a RET mutation. Even patients with MEN2B, which often have typical physical features, may not be properly recognized and be followed as a sporadic case. Based on this, all suspicious cases of multiple endocrine neoplasia should undergo a molecular genetic test.

Ackowledgements: This work was supported by grants from the São Paulo State Research Foundation (Fapesp) to RMBM (06/60402-1, BRASMEN Study) and to JMC (05/60330-8). The authors are grateful to J. Gilberto H. Vieira, Teresa S. Kasamatsu, and Magnus R. Dias da Silva for helpful discussions and to Angela Faria for secretarial support. JMC and RMBM are researchers of the Brazilian Research Council (CNPq). No potential conflict of interest relevant to this article was reported. We wish to thank all the Endocrinologists and Head and Neck Surgeons who referred their patients to the Medullary Carcinoma Clinic and all the team of the Adrenal Clinic at UNIFESP for the patients referred and for the assistance in the pheochromocytoma cases. This study is part of activities coordinated by the BRASMEN Project. The BRASMEN study is a data-basis of Brazilian patients with MEN2-related diseases generated by a consortium of several Brazilian universities.

\section{REFERENCES}

1. Kameyama K, Okinaga $\mathrm{H}$, Takami H. Clinical manifestations of familial medullary thyroid carcinoma. Biomed Pharmacother. 2004;58:348-50.

2. Lee YJ, Liu HC, Lee HC, Tzen CY, Huang CY, Yang TL. Picture of the month. Multiple endocrine neoplasia 2B syndrome. Arch Pediatr Adolesc Med. 2001;155:845-6.

3. de Krijger RR, Brooks A, van der Harst E, et al. Constipation as the presenting symptom in de novo multiple endocrine neoplasia type 2B. Pediatrics. 1998;102:405-8.

4. Erdogan MF, Gulec B, Gursoy A, et al. Multiple endocrine neoplasia 2B presenting with pseudo-Hirschsprung's disease. $J$ Natl Med Assoc. 2006;8:783-6.
5. Prabhu M, Khouzam RN, Insel J. Multiple endocrine neoplasia type 2 syndrome presenting with bowel obstruction caused by intestinal neuroma: case report. South Med J. 2004;97:1130-2.

6. Unruh A, Fitze G, Janig U, Bielack S, Lochbuhler H, Coerdt W. Medullary thyroid carcinoma in a 2-month-old male with multiple endocrine neoplasia 2B and symptoms of pseudo-Hirschsprung disease: a case report. J Pediatr Surg. 2007;42:1623-6.

7. Cuthbert JA, Gallagher ND, Turtle JR. Colonic and oesophageal disturbance in a patient with multiple endocrine neoplasia, type 2b. Aust N Z J Med. 1978;8:518-20.

8. Romeo G, Ceccherini I, Celli J, et al. Association of multiple endocrine neoplasia type 2 and Hirschsprung disease. J Intern Med. 1998;243:515-20.

9. Machens A, Ukkat J, Brauckhoff M, Gimm O, Dralle H. Advances in the management of hereditary medullary thyroid cancer. J Intern Med. 2005;257:50-9.

10. Machens A, Brauckhoff M, Holzhausen HJ, Thanh PN, Lehnert $\mathrm{H}$, Dralle H. Codon-specific development of pheochromocytoma in multiple endocrine neoplasia type 2. J Clin Endocrinol Metab. 2005;90:3999-4003.

11. Cranston AN, Carniti C, Oakhill K, et al. RET is constitutively activated by novel tandem mutations that alter the active site resulting in multiple endocrine neoplasia type 2B. Cancer Res. 2006;66:10179-87.

12. Miyauchi A, Futami $\mathrm{H}$, Hai $\mathrm{N}$, et al. Two germline missense mutations at codons 804 and 806 of the RET proto-oncogene in the same allele in a patient with multiple endocrine neoplasia type 2B without codon 918 mutation. Jpn J Cancer Res. 1999;90:1-5.

13. Gimm O, Marsh DJ, Andrew SD, et al. Germline dinucleotide mutation in codon 883 of the RET proto-oncogene in multiple endocrine neoplasia type 2B without codon 918 mutation. J Clin Endocrinol Metab. 1997;82:3902-4.

14. Smith DP, Houghton C, Ponder BA. Germline mutation of RET codon 883 in two cases of de novo MEN 2B. Oncogene.1997; 15:1213-7.

15. Menko FH, van der Luijt RB, de Valk IA, et al. Atypical MEN type $2 \mathrm{~B}$ associated with two germline RET mutations on the same allele not involving codon 918. J Clin Endocrinol Metab. 2002;87:393-7.

16. Chang A, Chan WF, Lo CY, Lam KS. Multiple endocrine neoplasia type 2B in a Chinese patient. Hong Kong Med J. 2004;10:206-9.

17. Byard RW, Thorner PS, Chan HS, Griffiths AM, Cutz E. Pathological features of multiple endocrine neoplasia type Ilb in childhood. Pediatr Pathol. 1990;10:581-92.

18. Maia AL, Gross JL, Punales MK. Multiple endocrine neoplasia type 2. Arq Bras Endocrinol Metabol. 2005;49:725-34.

19. Human Pathology Website. [available in 31 Aug 2008] <http:// www.humpath.com/MEN2B.

\section{Correspondence to:}

Rui M. B. Maciel

Laboratory of Molecular Endocrinology. Division of

Endocrinology, Department of Medicine, Federal University

of São Paulo

Rua Pedro de Toledo 669, $11^{\circ}$ andar

04039-032, São Paulo, SP, Brazil

E-mail: rui.maciel@unifesp.br 